\title{
STRATEGI STORYTELLING, SPREADABILITY DAN \\ MONETIZATION PODCAST SEBAGAI MEDIA BARU KOMEDI
}

\author{
Nadana Dalila $^{1}$, Niken Febrina Ernungtyas ${ }^{2}$ \\ ${ }^{1,2}$ Sekolah Tinggi Ilmu Komunikasi Inter Studi \\ Email: nadaezerdin13@gmail.com
}

\begin{abstract}
Abstrak
Podcast membuka ruang baru untuk berkarya dalam bidang audio. Podcast memiliki daya tarik tinggi di Indonesia, khususnya dari awal tahun 2019. Mudahnya akses untuk menjangkau media audio baru ini, terjadi peningkatan pendengar yang signifikan dalam proses perkembangannya. Tujuan penelitian ini adalah untuk mengetahui strategi storytelling, spreadability dan monetization podcast sebagai media baru komedi. Metode penelitian ini mengguankan paradigma konstruktivisme pendekatan kualitatif. Penelitian ini menemukan tiga strategi utama dalam pengelolaan podcast komedi yaitu strategi storytelling mengedepankan unsur alamiah, spreadability dengan menekankan pada promosi konten dan kolaborasi podcast dan monetization.
\end{abstract}

Kata Kunci: podcast, media baru, komedi

\begin{abstract}
Podcasts open up new spaces for playing in the audio field. Podcasts have had high traction in Indonesia, especially from the beginning of 2019. With easy access to this new audio media, there has been a significant increase in listeners in the process of development. The purpose of this research is to see the strategy of storytelling, spreadability, and podcast monetization as a new media for comedy. This research method uses the constructivism paradigm of a qualitative approach. This study found three main strategies in the management of comedy podcasts, namely storytelling strategies that prioritize natural elements, their distribution by emphasizing promotional content and podcast collaboration and monetization.
\end{abstract}

Keywords: podcast, new media, comedy 


\section{PENDAHULUAN}

Podcast merupakan sebuah media audio baru yang dikenal sejak tahun 2004. Podcast telah menunjukkan peningkatan tren penyampaian audio dalam format yang baru dan cukup signifikan. Sebagai sebuah media audio baru, podcast dapat diartikan sebuah materi audio atau video yang tersedia di internet atau melalui aplikasi secara gratis maupun berlangganan (Fadilah, Yudhapramesti, \& Aristi, 2017). Di Amerika Serikat (AS), tempat pertama kali podcast lahir, ditunjukkan bahwa 21\% warga Amerika Serikat usia 12 tahun keatas, pasti pernah menjadi pendengar podcast dalam dalam satu bulan terakhir (Pew Research Center, 2016). Seorang pendiri seri podcast bernama "startup" yaitu Alex Blumberg, mengungkapkan bahwa sekarang (siaran) audio berpindah pada jenis on demand atau sesuai kebutuhan (Zaenudin, 2011).

Walaupun masih terbilang sebagai media audio alternatif radio, podcast memiliki perkembangan yang cukup pesat karena sifatnya yang mudah diterima oleh para audience. Seperti salah satu penelitian yang telah dilakukan oleh Bongey, Cizadlo \& Kalnbach (2006), para peneliti menyediakan podcast ke beberapa siswa di sebuah perguruan tinggi. Menggunakan sedikit waktu dan pengalaman, peneliti mulai merasakan sifat viral dari podcast yang disebarkan, ketika sebuah pengetahuan dan penggunaan podcast baru menyebar dengan cepat dari satu pendengar ke yang lain. Distribusi podcast sudah melampaui parameter kampus atau siswa. Setelah podcast berhasil menyebar luas, Cizadlo mulai menerima pesan email dari luar dan pendengar non AS dan mendapatkan respon yang cukup baik (Bongey, Cizadlo, \& Kalnbach, 2006).

Proses perkembangan yang bisa dikatakan berhasil di Amerika Serikat, podcast akhirnya melebarkan sayapnya hingga ke Indonesia. Pintu masuk podcast dapat terbuka dengan lebar di Indonesia diawali dengan tersedianya kanal podcast di spotify pada tahun 2018 (Samosir \& Putra, 2020). Keberhasilan podcast di Indonesia juga sudah mulai terlihat dari tahun 2018, yaitu dengan melihat hasil survei yang dilakukan DailySocial dengan melibatkan 2032 responden. Survei tersebut mendapatkan hasil hampir 68 persen responden menyatakan akrab dengan podcast dan 80 persen diantaranya telah mendengarkan podcast dalam enam bulan terakhir (Namira \& Wicaksono, 2020). Hingga bulan Mei 2020 kemarin, perkembangan podcast di Indonesia semakin pesat. Saat ini Indonesia mencapai jumlah pendengar terbanyak se-Asia Tenggara, dengan 20 persen pengguna mendengarkan podcast yang ada di setiap bulannya (Kumparan.com, 2020).

Podcast memiliki 4 karakteristik utama yang menjadi ciri khasnya dibandingkan media audio lain yaitu episodic, download, dan streaming, dan memiliki tema yang segmented. Podcast sendiri terbagi menjadi tiga jenis podcast, yang pertama audio podcast, podcast yang paling umum berbentuk file MP3, yang kedua peningkatan podcast yang menggunakan visual dan disertai dengan audio seperti di Youtube, dan yang ketiga video podcast, yang berisikan film dengan dilengkapi suara serta biasanya berbentuk format MP4 (Toyib, Humaisyi, \& Muzakki, 2013). Podcast juga menyiarkan berbagai macam topik yang berbeda sehingga memungkinkan pendengar memiliki 
banyak pilihan topik untuk didengar. Seperti topik mengenai bisnis, desain, startup, film, teknologi, game, animasi dan komedi. Di Indonesia, podcast yang bertopik komedi begitu sangat digemari oleh pecintanya (Indovoiceover, 2019).

Komedi sudah menjadi salah satu pilar budaya media digital di abad ke-21. Mobilitas lintas platform merupakan salah satu alasan komedi cocok untuk konteks produksi, distribusi, serta konsumsi media digital (Marx, 2015). Terkait dengan podcast khususnya podcast yang bertema komedi, penyiar podcast komedi terbiasa memiliki unsur unik tersendiri, yaitu naturalisasi. Unsur unik yang terdapat didalam podcast, menawarkan potensial untuk presentasi diri yang lebih 'asli', atau menawarkan sebuah persepsi yang meyakinkan tentang dirinya (naturalisasi). Untuk memahami bagaimana komedian ini mempertahankan 'keaslian' dirinya melalui podcasting, dan hal ini akan bermanfaat untuk mempertimbangkan preseden yang ada di media lama, yang juga memiliki prinsip sama (Symons, 2017).

Penyajikan podcast, podcaster terbiasa menyajikan sesuatu sesuai dengan gaya bicara mereka masing-masing. Salah satu penyampaian dapat dilakukan dengan storytelling yang dapat diartikan sebagai salah satu cara yang dilakukan untuk menyampaikan suatu cerita kepada para penyimak, baik dalam bentuk kata-kata, gambar, foto, maupun suara. Storytelling merupakan suatu teknik untuk menceritakan sebuah kisah, dialog, pengaturan adegan, bahkan sebuah event (Thaba, 2013). Dalam era saat ini podcast merupakan salah satu suatu bentuk baru dari digital storytelling. Di samping itu, digital storytelling dapat mencakup berbagai macam topik tidak terbatas dan dapat diakses dari berbagai software yang tersedia (Asri, Indrianti, \& Perdanasari, 2017). Sehingga podcast dapat digunakan sebagai media storytelling dimana saja dan kapan saja.

Di Indonesia, podcast memiliki spreadaility yang cukup tinggi. Spreadability dalam studi media bisa diartikan sebagai proses penyebarluasan atau sirkulasi informasi pada sebuah platform media ( Jenkins, Ford, Green, 2013 ). Dalam proses spreadability, podcast mengalami peningkatan jumlah pendengar yang cukup tinggi. Dengan adanya platform penyedia podcast, seperti Anchor, Spotify, Soundcloud, dan Youtube juga menjadi salah satu faktor pendukung hal tersebut. Hasil survei hanya di platform spotify menyatakan bahwa, untuk kuartal-II tahun 2019 layanan streaming musik spotify memiliki peningkatan sebesar 50 persen untuk jumlah pendengar streaming podcast dibandingkan dengan kuartal sebelumnya. Jumlah pendengar podcast spotify pun nyaris dua kali lipat lebih banyak dibandingkan yang tercatat di awal tahun 2019. Hal tersebut merupakan kabar baik pula untuk spotify (Pertiwi, 2019).

Ketersediaan podcast pada media audio digital memiliki peminat yang sangat banyak dan menjadi sebuah penghasilan yang cukup menjanjikan pula. Di Indonesia hasil survei yang dilakukan Daily Social yang berkerjasama dengan JakPat Mobile Survei Platform dengan melakukan survei terhadap 2023 pengguna ponsel pintar, menanyakan tanggapan masyarakat Indonesia terhadap podcast. Hasil dari survei tersebut mengatakan bahwa, konten $(65,00$ persen) dan fleksibilitas akses (62,69 persen) menjadi faktor yang dianggap menarik bagi responden, untuk memilih podcast sebagai salah satu media audio 
alternatif pendengar. Selain itu hasil survei juga mengatakan bahwa, Spotify $(52,02$ persen) adalah layanan paling populer yang digunakan untuk mendengarkan konten podcast oleh responden (Eka, 2018).

Meningkatnya minat pendengar terhadap podcast, podcaster juga dapat memonetisasi podcast yang dibuat. Monetisasi adalah salah satu cara untuk menghasilkan uang dengan mengemas pesan komersial dalam bentuk konten yang menarik dan dapat dinikmati (Febriani \& Fadilah, 2019). Salah satu caranya yaitu dengan menawarkan beberapa pengiklan untuk menaruh iklan yang sesuai dengan konten atau segmentasi pendengar dari podcast tersebut. Iklan yang ditawarkan dapat berbentuk adlibs yaitu iklan yang dibacakan penyiar misalnya. Selain melalui iklan, podcast juga dapat menghasilkan uang melalui aplikasi penyedia podcast.

Podcast yang dibuat tidak hanya disebarkan melalui satu platform saja, contohnya podcast dapat disebarkan melalui youtube dengan melibatkan visual. Menyebarkan podcast di youtube kreator podcast dapat menghasilkan uang melalui "adsense". Lain hal pula dengan aplikasi penyedia podcast yaitu anchor, di Amerika Serikat kreator anchor sudah mengaktifkan fitur donasi yang tersedia di dashboard tepat pada profile anchor. Setelah melalui tahapan tersebut akan muncul sebuah tombol berlabel "Listener Support", dan dilengkapi dengan tautan pada deskripsi podcast yang diberi donasi. Adanya fitur ini pendengar podcast dapat langsung memberikan dukungan dalam bentuk uang. Fitur donasi ini bahkan sudah menjangkau ke beberapa aplikasi penyedia podcast. Tidak hanya melalui aplikasi anchor, tapi dari aplikasi podcast bawaan iOS maupun google podcasts sudah tersedia (Kaonang, 2018).

\section{METODE PENELITIAN}

Penelitian ini menggunakan paradigma penelitian konstruktivisme dan pendekatan penelitian kualitatif. Penelitian ini memahami konsep awal penyampaian materi komedi sampai proses akhir penyampaian komedi. Hal ini dapat dilihat dengan memahami proses storytelling konten kreator, spreadability, dan monetization dari beberapa pembuat podcast komedi di Indonesia. Menurut Bogdan dan Taylor (1975), penelitian kualitatif adalah bentuk penelitian yang memiliki data deskriptif berupa katakata tertulis atau lisan dari orang-orang serta perilaku yang dapat diamati (Moleong, 2012). Penggunaan pendekatan kualitatif dilakukan karena dianggap pendekatan ini lebih sesuai untuk dapat menemukan data yang valid dan reliabel tentang aspek-aspek yang akan diteliti, dengan pendekatan kualitatif pengamatan terhadap objek penelitian akan lebih mendalam, sehingga data yang didapatkan lebih akurat (Marlina, 2016).

Teknik pengumpulan data dilakukan dengan teknik wawancara. Wawancara termasuk ke dalam salah satu bagian dari metode kualitatif. Metode kualitatif, teknik wawancara yang digunakan adalah wawancara mendalam (in-depth Interview). Wawancara mendalam (in-depth Interview) adalah proses untuk mendapatkan suatu keterangan sebagai tujuan penelitian dan menggunakan sistem tanya jawab langsung dengan informan, responden atau orang yang diwawancarai. 
Tabel 1. Data Informan Penelitian

\begin{tabular}{cccc}
\hline $\begin{array}{c}\text { KARAKTERISTIK } \\
\text { INFORMAN }\end{array}$ & $\begin{array}{c}\text { INFORMAN } \\
\mathbf{1}\end{array}$ & $\begin{array}{c}\text { INFORMAN } \\
\mathbf{2}\end{array}$ & $\begin{array}{c}\text { INFRMAN } \\
\mathbf{3}\end{array}$ \\
\hline NAMA INFORMAN & Audy Syalendra & $\begin{array}{c}\text { Nastasha Abigial } \\
\text { Koetin }\end{array}$ & Handaru \\
NAMA & Serius Banget Gak & Sih \\
PODCAST & Podcast & $\begin{array}{c}\text { Rapot } \\
\text { Podcast }\end{array}$ & Podcast Pojokan \\
\hline USIA & 23 Tahun & 33 Tahun & 25 Tahun \\
\hline STATUS PEKERJAAN & Mahasiswa & Announcer & Karyawan Swasta \\
\hline
\end{tabular}

\section{SUMBER : Olah Data Penelitian}

Penelitian ini melibatkan tiga orang podcaster sebagai informan. Ketiga informan ini terpilih dikarenakan keterlibatan informan dengan podcast genre komedi. Ketiga nforman memiliki latar belakang pendidikan yang berbeda, namun ketiga informan ini merupakan seorang podcaster sekaligus salah satu konten kreator dari beberapa podcast komedi di Indonesia. Wawancara dilakukan dengan masing-masing informan secara terpisah, serta waktu dan tempat yang berbeda. Wawancara dilakukan dengan melibatkan audio, tanpa melibatkan visual. Setelah wawancara selesai dilaksanakan, hasil rekaman dari wawancara di transkrip menjadi verbatim dan ditempatkan pada halaman lampiran dari penelitian ini.

Setelah transkrip, dilakukan proses analisis data yang pertama yaitu memilah mana hal yang penting dan mana yang tidak. Tahap kedua adalah dengan memberi tambahan mengenai komponen teks yang terkesan meragukan individu seperti istilah atau kalimat untuk menjelaskan teks tertentu. Proses analisis yang terakhir yaitu, menyaring aspek-aspek penting dari sebuah materi yang telah distruktur dengan memperhatikan isi, bentuk hingga skala-skala tertentu (Sya, Marta, \& Hadi, 2020). Dilanjutkan dengan proses koding dengan memasukkan dialog penting yang sudah dipilih ke dalam sebuah tabel dimana nanti tabel akan terdiri dari tiga proses coding, mulai dari open coding, axial coding, hingga selective coding.

\section{HASIL DAN PEMBAHASAN}


Berdasarkan penelitian yang dilakukan, terdapat hasil temuan yang dapat menggambarkan proses pembuatan podcast atau pun alasan mengapa podcast bisa dikenal di Indonesia beberapa akhir tahun ini, dengan meninjau hasil penelitian yang menggunakan sudut pandang penelitian dari sisi content creator podcast yang diteliti. Melalui hasil wawancara yang dilakukan melalui tiga informan yang memiliki latar belakang sebagai podcaster, wawancara berhasil dilakukan dengan durasi 25-60 menit. Hasil wawancara yang diperoleh, dialog yang dilakukan saat wawancara telah ditranskip ke dalam sebuah teks. Setelah melalui proses transkrip, hasil data diolah melalui proses coding. Melalui tahap akhir dari proses coding yaitu selective coding, telah ditemukan bahwa ada tiga tema selective coding yaitu; storytelling, spreadability dan monetization beserta beberapa temuan axial yang berisikan berbagai hal pendukung strategi yang dijalankan pada podcast, yang ternyata memiliki banyak peranan penting dalam pembuatan serta kemajuan dari sebuah perkembangan media podcast hingga podcaster itu sendiri, tidak hanya dari sisi komedi yang disampaikan namun juga dari sisi podcaster ataupun proses monetisasinya. 
Tabel 2. Tabel Ringkasan Hasil Analisis

\begin{tabular}{|c|c|c|c|}
\hline & Informan 1 (AS) & Informan 2 (HD) & Informan 3 (NA) \\
\hline Latar belakang Pendidikan & Mahasiswa Komunikasi Bisnis & S1 IT Programming & S1 Jurnalistik \\
\hline
\end{tabular}

Alasan awal membuat podcast

Mencari media yang dapat menjadi wadah berbincang tanpa batasan-batasan tertentu

Tahun 2019 bulan Juli, kuranglebih 6 bulan

Jumlah Plays : Palinng banyak 1.400 plays (episode toxic relationship)

Pendengar

Karakteristik : Lebih banyak laki-laki yang suka perbincangan mengenai hal-hal 17 tahun keatas.

Segmentasi Usia : 18-24 Tahun

Ciri khas : tipe suara
Diajak teman, dan teman yang mengajak punya cita-cita menjadi penyiar radio

Februari 2016, kuranglebih 4 tahun

Jumlah Plays : Paling banyak 7.000 plays (episode zona nyaman)

Karakteristik : Orang jakarta yang sering menggunakan bahasa betawi dan suka mendiskusikan berbagai macam hal bersama.

Segmentasi Usia :12-30 Tahun

Ciri khas : Pilihan kata dan cara bicara
Berawal dari nostalgia dan memiliki background sebagai penyiar radio dan ingin menghidupkan nostalgia tersebut kembali Maret 2019, kurang lebih satu tahun

Jumlah Plays : 3,2 Juta Plays (Seluruh episode hingga januari 2020)

Karakteristik : Lebih banyak perempuan.

Segmentasi Usia :

Tidak diatas 30 tahun.

Ciri khas : Sifat diri sendiri, yaitu tidak selalu sepakat dengan perkataan partner berpodcast.

Persiapan materi : chat via group lanjut diskusi 
Persiapan materi: membuat timeline topik 2- Persiapan materi : Segala hal dapat dijadikan hari-h recording untuk menentukan tema apa 4 dalam satu kali diskusi, satu minggu untuk sebuah materi, seperti berita atau tweet dll $\quad$ yang dipilih. menyiapkan materi yang akan dibaha

Basic comedian: tidak ada menyampaikan sesuatu: Suka bercand dengan teman dekat dan menyukai kontenkonten komedi.
Basic comedian: tidak ada

Komedi Podcast

\section{Alasan muncul unsur candaan saa}

menyampaikan sesuatu: hal dengan melibatkan unsur candaan dan hal tersebut biasa dilakukan bersama teman sekitar.
Terbiasa melakukan diskusi mengenai suatu

Basic comedian: tidak ada

Alasan muncul unsur candaan saat menyampaikan sesuatu:

Suka bercanda dengan teman sekitar, menyukai serial komedi diyoutube dll.

\section{Offline: Mulut ke mulut}

Online: Instagram pribadi dan Instagram Podcast

\section{Offline :Mulut ke Mulut}

Online : Instagram Pribadi, Instagram podcast, dan promosi dari brand yang terlibat
Offline : Mulut ke mulut

Online : Instagram pribadi dan Instagram Podcast kerjasama.

Masuk agency podcast, collab antar podcast Membuat podcast menjadi sebuah brand yang dan Membuat komunitas podcast (sudah dapat masuk ke berbagai aktivasi dan collab dijalankan)

antar podcast (sudah dijalankan)

\section{(sudah dijalankan)}

Pendapatan

podcast

Ratecard yang ditawarkan per-event
Rp.2.500.000

Tidak memili Rp.600.000

Multiplatform podcast
Ingin mencoba untuk membuat konten youtube dari podcast yang dimiliki saat ini
Tidak terta
Start from Rp.20.000.000 (Full team)

Tertarik untuk membuat konten visualisasi podcast asalkan tidak hanya memiliki fungsi yang sama dengan konten podcast yang disajikan dalam audio. 
Karir sebagai podcaster

Berniat menjadikan podcaster sebagai karir, apabila ada saatnya diberikan peluang yang sebesar-besarnya untuk menghasilkan dalam bidang yang dijalani.
Tidak terlalu berambisi untuk menjadikan Tetap terbuka dengan perubahan atau podcaster sebuah karir,akan selalu berpodcast perkembangan media, terus berkarya dalam selama masih memiliki wadah hiburan yaitu podcast dan mengikuti arus tanpa meniatkan dengan menjadi podcaster dalam sebuah ini sebagai karir kedepannya. podcast yang dimiliki.

\section{SUMBER : Olah Data Penelitian}




\section{Storytelling}

Strategi storytelling dalam podcast dapat dilakukan melalui berbagai hal yang telah disampaikan oleh para informan melalui hasil wawancara. Cara-cara tersebut terdiri dari 12 hal yaitu seperti yang pertama, dengan memperhatikan ciri khas podcaster. Seluruh informan menyebutkan bahwa mereka memiliki ciri khasnya masing-masing. Namun tetap ciri khas yang mereka miliki dapat timbul ketika mereka menjadi diri mereka sendiri. Dengan cara penyampaian yang mereka sampaikan saat membawakan materi dan suara yang mereka miliki dapat menjadikan suatu ciri khas yang dimiliki oleh tiap podcaster. Hal ini terkonfirmasi dari informan (AS) yang menyatakan: "itu di ketawa sama di tipe suara gue” (Informan AS; 6 Januari 2020).

Selain ciri khas podcaster hal kedua yang menjadi salah satu strategi storytelling yaitu, dengan memperhatikan persiapan sebelum rekaman podcast. Menurut data yang diperoleh dari hasil wawancara, persiapan untuk melakukan rekaman podcast dilakukan sebelum hari $\mathrm{H}$ rekaman dilaksanakan. Persiapan terdiri dari diskusi awal, lanjut ke pemilihan topik, dan terakhir eksekusi topik atau proses rekaman. Pada proses persiapan ini segala sesuatu hal dapat dijadikan topik pembicaraan dan topik juga dapat berasal dari mana saja. Seperti yang dikatakan salah satu informan (HD) menyatakan: "sebenernya karena dari kita baca berita jadi materi, dari kita ngeliat tweet-tweet orang jadi materi" (Informan HD; 11 Januari 2020).

Setelah persiapan telah dilakukan ada baiknya melakukan proses produksi dan dalam proses produksi sangat dibutuhkan pengaturan waktu yang tepat dengan memperhatikan manajemen waktu dalam podcast sebagai hal ketiga dalam strategi storytelling. Hal yang membuat time management penting adalah agar kita terbiasa menceritakan segala sesuatu mengenai suatu topik secara efektif tanpa mengulangngulang apa yang sudah kita katakan, seperti yang disampaikan salah satu informan yaitu (HD) yang menyatakan: "sadar atau gasadar sebenernya dititik tertentu obrolannya lu sama temen lu pasti muter. Nah ketika lo udah sampe titik itu menurut gue stop aja" (Informan HD; 11 Januari 2020). Dan bahkan salah satu podcaster juga menyebutkan bila suatu podcast memiliki tim lengkap melebihi dua orang diluar podcaster, ada baiknya salah satu anggota tim bertugas menjadi time keeper. Hal tersebut terkonfirmasi dari (AS) yang menyatakan: "Ada time keeper sihh sebenernya si produser time keepernya" (Informan AS; 6 Januari 2020).

Podcast sebagai salah satu bentuk media hiburan, penting bagi podcaster juga memiliki sedikit pengetahuan dalam bidang yang diselami, hal ini merujuk kepada strategi keempat yaitu minat dalam komedi. Untuk membuat kita bisa menciptakan suatu komedi semua berangkat dari kesukaan atau kebiasaan yang kita lakukan. Hal ini terlihat dari pernyataan yang dikatakan oleh (AS): "Gue suka becanda sama temen temen gua, gua suka nonton komedi" (Informan AS; 6 Januari 2020). Dan selain itu pernyataan ini didukung juga oleh informan (NA) yang mengatakan: “jadi gua sukak memang nonton 
film komedi, tapi gue kebanyakan nontonnya satir, komedi-komedi satir. Gue suka nontonin video-video di youtube yang sketsa-sketsa gitu" (Informan NA; 3 Februari 2020). Dengan kebiasaan menyaksikan hal yang berhubungan dengan komedi membawa mereka menjadi semakin tertarik kedalam hal yang berbau dengan hiburan. Hal tersebut juga membuat salah satu dari informan mengatakan penting untuk mmperhatikan hal dasar yang harus diketahui dalam menjadi seorang komedian. Untuk menjadi seorang komedian yang berhasil hanya memerlukan referensi mengenai berbagai macam hal yang ada. Hal ini dikonfirmasi dari informan (NA) yang menyatakan: "Salah satu bekal menjadi komedian adalah punya referensi pengetahuan yang banyak, sebanyakbanyaknya" (Informan NA; 3 Februari 2020).

Setelah memiliki pengetahuan yang cukup mengenai hal yang diselami, strategi yang dilakukan selanjutnya adalah mengutamakan orisinalitas materi. Pernyataan sebelumnya mengenai materi mengatakan bahwa materi dapat berangkat dari mana saja. Namun tetap setiap materi harus memiliki sisi originalitasnya sendiri, baik berupa pengalaman pribadi atau pengalaman orang sekitar yang mungkin pernah diceritakan atau didengar langsung oleh podcaster sendiri. Pernyataan ini terkonfirmasi dari kedua informan yaitu informan (NA): "random, tapi semuanya itu true story karena berdasarkan pengalaman sendiri" (Informan NA; 3 Februari 2020) dan informan (AS) yang menyatakan: "Yang paling penting itu harus berangkat dari kehidupan pribadi kita dulu” (Informan AS: 6 Januari 2020).

Originalitas materi yang dimana berhubungan topik juga menjadikan kita untuk berfikir menjurus ke arah hal yang ketujuh yaitu, topik yang mendominasi. Masingmasing podcast memiliki tolak ukur untuk memilih topik yang ingin disampaikan, bahkan dengan komedi saja bisa ada komedi tertentu yang ditonjolkan dalam sebuah podcast. Hal ini dikonfirmasi melalui informan (HD) yang menyatakan: "kritik dengan cara komedi yakan. Nah itu sebenernya mungkin konten gue banyak soal itu, gitu" (Informan HD; 11 Januari 2020). Bahkan ada podcast yang menyeleksi topik mayoritas mereka, sesuai dengan target audience yang dimiliki, seperti yang dikonfirmasi informan (AS) yang menyatakan: "kita berusaha gimana caranya itu pembahasan yang kita bahas relate sama anak-anak muda" (Informan AS; 6 Januari 2020).

Berdasarkan hasil wawancara dengan ketiga informan, mereka mengatakan apabila partner dalam podcast mereka diganti, itu akan mempengaruhi jalannya podcast mereka. Maka dari itu pengaruh partner siaran menjadi bagian strategi storytelling selanjutnya. Pengaruh yang didapatkan pun dapat berupa pengaruh baik maupun buruk. Hal ini salah satunya dikonfirmasi oleh informan (NA) yang menyatakan: "Pastinya emang ngaruh deh. Pengaruh karena em..pengaruhnya bisa baik bisa buruk ya, buruknya bisa kaya kita butuh penyesuaian lagi karena sebenerny terbentuk ber-4 ini kan juga ada latar belakangnya, pengaruh baik juga karena kita jadi punya referensi baru dan sebagainya" (Informan NA; 3 Februari 2020).

Setelah meninjau sisi pengaruh dari partner siaran, pengaruh lainnya yang masuk kedalam strategi storytelling dalam podcast yaitu, pengaruh intonasi. Dalam hal intonasi 
beberapa informan memiliki pendapat yang berbeda dan dapat dilihat dari hasil wawancara yang dilakukan. Ada yang memiliki pendapat bahwa bagaimana cara kita menyampaikan materi pada saat proses rekaman berlangsung serta penggunaan intonasi adalah kedua hal yang penting, seperti yang dikatakan salah satu informan yaitu (NA) : "bagaimana kita menyampaikan tuh penting banget, mau itu komedi terus ataupun pesen-pesen, itu intonasi makanya ngaruh banget ke em..bagaimana pesan itu akan tersampaikan efektif atau engga" (Informan NA; 3 Februari 2020). Namun berbeda hal dengan informan lain yang menganggap intonasi tidak menjadi hal utama yang harus diperhatikan ketika memang materi atau topik yang dibawakan sudah sangat dimengerti oleh pendengar dan memiliki unsur hiburan didalamnya, hal ini dikonfirmasi oleh (HD): "penekanan suaranya gaterlalu penting, gitu. Selama orang masih ngerti apa yang gua omongin dan masih lucu” (Informan HD; 11 Januari 2020).

Masih dalam hal komedi, berhubungan dengan informan yang telah diwawancarai, podcast yang mereka jalankan sering dikategorikan sebagai podcast komedi, dan melalui hasil data yang diperoleh dari wawancara tersebut, podcast yang saat ini dinilai sebagai podcast komedi oleh para pendengar mereka ternyata tidak pernah memiliki tujuan awal menjadi podcast komedi dan hal tersebut datang dengan sendirinya tanpa direncanakan oleh pihak pembuat podcast bahkan platform penyedia podcast yang ada. Hal ini dikonfirmasi oleh informan (NA) yang menyatakan: "Untuk pocast komedi..nah kalau RAPOT sendiri itu gapernah punya intensitas "gua pengen ngelucu nih, gitu" (Informan NA; 3 Februari 2020). Kembali lagi dalam membahas suatu komedi atau membawakan sesuatu yang berbau candaan dalam suatu konten podcast dapat dilakukan secara fleksibel dengan pilihan komedi apapun, asalkan tidak menjelekkan nama baik seseorang atau beberapa pihak tertentu. Dan hal ini berujuk kepada hal lainnya yaitu mengenai sudut pandang humor atau komedi yang dibawakan. Hal ini didukung dengan pernyataan yang dapat dikonfirmasi dari informan (NA) yang menyatakan: "Menurut gua semua hal itu bisa, kan komedi tuh sudut pandang ya, jadi menurut gua topik apapun tuh bisa dilihat dari sudut pandang humor asalkan, kalau prinsip gua dan mungkin temen-temen rapot lainnya ya. Asalkan mentertawakannya itu lebih baik diri sendiri dibandingkan orang lain" (Informan NA; 3 Februari 2020).

Hal terakhir dalam storytelling yaitu aturan dalam berbicara. Dalam podcast tidak ada aturan pasti dalam proses bicara yang dilakukan para podcaster (bila podcast terdiri lebih dari satu podcaster) saat penyampaian materi, hal ini dikonfirmasi oleh informan (HD) yang menyatakan: "gue tidak punya aturan ketika orang lain ngomong gue harus berenti, atau sebaliknya” (Informan HD; 11 Januari 2020). Karena ada beberapa podcaster yang memang sudah memiliki kemampuan dasar sebagai penyiar radio dan terbiasa untuk mengatur jeda bicara mereka pada saat sedang melakukan penyampaian materi. Hal tersebut dikonfirmasi oleh informan (NA) yang menyatakan; "itu jadi sebuah keuntungan sih karena kita udah temenan plus em.. kita pernah siaran, kita tau gimana caranya supaya ga tumpuk-tumpukkan..ibaratnya gitu” (Informan NA; 3 Februari 2020) 


\section{Spreadabillity}

Selain mengenai strategi penyampaian yang dilakukan, selanjutnya yaitu dalam strategi penyebarluasan podcast yang ada. Bila ditinjau kembali, ada sepuluh hal yang digunakan dalam strategi penyebarluasan podcast. Pertama yaitu promosi podcast, dimana promosi podcast dapat dilakukan melalui dua cara, yaitu melalui media sosial atau tanpa menggunakan media sosial. Proses promosi podcast salah satunya dapat dilakukan melalui media sosial, sehubungan dengan era digital saat ini, bahkan podcast sendiri hanya dapat diakses secara digital saja. Dan promosi melalui media sosial yang dilakukan podcaster adalah dengan mengutamakan media sosial Instagram dari podcast mereka maupun Instagram personal pribadi masing-masing. Hal tersebut didukung oleh pernyataan dari informan (AS) yang menyatakan: "Kalau untuk promosinya udah pasti pertama dari instagram si sbgs podcast sama instagram kita pribadi masing-masing per anak-anak" (Informan AS; 6 Januai 2020). Selain untuk promosi Instagram juga dapat melancarkan proses engangement dengan pendengar yang ingin mereka tingkatkan, hal ini dikonfirmasi dari (HD) yang menyatakan: "tapi beberapa enggagement gue lakuin melalui sosial media, gitu” (Informan HD; 11 Januari 2020). Promosi podcast dilakukan untuk meningkatkan jumlah pendengar dan menambah eksistensi podcast tersebut. Promosi tanpa media sosial juga dapat dilakukan dengan cara seperti mengadakan podcast siaran langsung disuatu tempat, datang menjadi pembicara dengan mengatasnamakan podcast atau melakukan kolaborasi dengan podcast lain.

Ketiga hal tersebut dikonfirmasi oleh para informan yaitu (AS) yang menyatakan: "live podcast kalau memang kita yang buat sendiri itu tujuannya bukan buat nyari duit malah kita yang keluar duit disitu, nah apa ya biar orang tuh paham gituloh misalkan dia bener bener gatau podcast" (Informan AS; 6 Januari 2020), dan informan (NA) yang menyatakan: "Nah kita tuh paling salah satu yang akhirnya jadi medium promosi ya kalau kita diundang dan datang sih" (Informan NA; 3 Februari 2020) atau pernyataan dari informan (HD) yang menyatakan: "promosi konten ini, menurut gue bukan dengan media seperti Instagram, Whatsapp dan lain lain, tapi lu ikut ke podcast orang lain menurut gue memperkenalkan podcast di podcast orang lain, jadi lu kolaborasi" (Informan HD; 11 Januari 2020). Setelah dua hal diatas dalam sisi promosi, masih ada hal lain juga yang diperhatikan dalam proses promosi khususnya dari sisi media sosial podcast dan menjadikan kepentingan visual untuk promosi menjadi komponen ketiga dari strategi spreadability podcast. Dengan menggunakan Instagram sebagai salah satu media promosi podcast, podcaster harus juga mempertimbangkan sisi visualisasi dari podcast selain mengutamakan unsur audionya. Hal ini dikonfirmasi dengan pernyataan informan (NA) yang menyatakan: "di RAPOT ya gue tetep merasa visual itu penting makanya setiap covernya kalau misalnya lo perhatiin yang suka kita post di Instagram itu memang juga di design per-topik" (Informan NA; 3 Fabruari 2020).

Terlepas kepentingan promosi, melihat jumlah keseluruhan pendengar podcast atau episode terbanyak juga menjadi komponen penting spreadability untuk mengevaluasi bagaimana perkembangan podcast tersebut. Masing-masing podcast dapat 
mengetahui jumlah pendengar mereka melalui aplikasi Anchor yang disediakan untuk mengunggah podcast ke platform yang tersedia seperti Spotify. Setiap podcast memiliki jumlah pendengar masing-masing. Hal ini dikonfirmasi oleh ketiga informan yang pertama informan (AS) yang menyatakan: "jumlah pendengar paling banyak itu ada di episode toxic relationship, perbulan november kemarin tuh 1400 untuk toxic doang" (Informan AS; 6 Januari 2020), yang kedua informan (HD) yang menyatakan: "paling banyak 6000 eh 7000 nih yang.. episodenya keluar dari zona nyaman" (Informan HD; 11 Januari 2020) dan yang ketiga yaitu informan (NA) yang menyatakan: "pokoknya total playsnya itu udah 3,2 juta untuk semua episode sampe bulan Januari kemaren. Pendengarnya itu udah 352.502" (Informan NA; 3 Februari 2020).

Berkaitan dengan jumlah pendengar ada juga hal lain yang dapat dilihat yaitu, segmentasi pendengar. Mengetahui jenis kelamin, usia, dan lokasi masing-masing pendengar yang terdaftar dapat mempermudah podcaster untuk mengetahui konten apa yang sesuai dan siapa target pendengarnya (Waves8.com, 2020). Maka dari itu setiap podcast memiliki target audiencenya masing-masing. Hal tersebut dinyatakan oleh masing-masing informan. Informan (AS) menyatakan: "segmen-segmen SBGS itu anakanak muda, umurnya itu dari, kalau anak-anak mudanya umurnya dari 18-24, 60\% cowo" (Informan AS; 6 Januari 2020).

Selanjutnya informan (HD) menyatakan: "range umurnya tuh dari 12 tahun sampe dia sadar kalau dia butuh content yang lebih mature, mungkin itu range umurnya 28, 29, 30 gitu..Itu range orang yang dengerin podcast gue" (Informan HD; 11 Januari 2020), dan yang terakhir informan (NA) menyatakan: "pendengarnya gendernya itu lebih banyak perempuan dibandingkan laki-laki, usianya paling banyak 23-27 tahun itu 45\% terus em..terus yang kedua 18-22 tahun itu 34\%, terus 28-34 16\% terus selebihnya ada diatas 34 tahun" (Informan NA; 3 Februari 2020).

Tidak berhenti pada segmentasi selanjutnya demografis pendengar podcast. Podcast dari Indonesia tidak hanya dapat diakses di dalam negeri saja, namun podcast juga dapat diakses hingga ke luar Indonesia. Namun tetap pendengar podcast Indonesia masih seputar masyarakat Indonesia yang mungkin bertempat tinggal diluar negeri, karena basis bahasa utama yang digunakan dalam podcast di negara ini masih bahasa Indonesia. Hal ini dikonfirmasi dari informan (NA) yang menyatakan : "paling banyak lokasinya di Indonesia tapi ada ada juga di Amerika, Australia, Jerman em..UK, Malaysia, Singapura, Jepang, Belanda sama Canada..ini juga orang Indonesia sebenernya karena kita basednya bahasa Indonesia. Kalau di Indonesianya di Jakarta 52\% selebihnya tersebar ada West Java, East Java, Central Java” (Informan NA; 3 Februari 2020).

Untuk memperluas fungsi podcast, ada juga yang ingin menjadikan podcast multiplatform, dan tidak terbatas hanya dalam audio saja dan menjadikannya sebagai salah satu spreadability yang harus diperhatikan. Podcast di era saat ini telah memiliki bentuk tidak hanya audio, tapi juga memiliki bentuk visual seperti podcast yang dipublikasikan di media Youtube. Dua dari ketiga informan kurang berminat untuk 
menjadikan podcast mereka multiplatform ke media Youtube apabila isi konten yang dimiliki tidak jauh berbeda dengan apa yang disajikan di Spotify. Hal ini dikonfirmasi oleh salah satu informan yaitu (NA) yang menyatakan: "menurut gue lagi-lagi kayak sayang karena itu lo punya keunggulan masing-masing kenapa lo dengerin di podcast kenapa lo dengerin di youtube, kecuali RAPOT misalnya bisa bikin sesuatu di youtube berbeda dengan konten di podcast, itu baru jadi efektif " (Informan NA; 3 Februari 2020).

Proses perkembangan podcast tidak semata-mata hanya melalui promosi atau mengukur jumlah pendengar, melainkan juga memikirkan strategi spreadability yang lain dalam mengembangkan konten yang disajikan. Menurut data hasil wawancara dengan informan, ternyata strategi yang lebih diutamakan dalam podcast dibandingkan promosi adalah strategi untuk mengembangkan konten, baik dari sisi aspek pembawaan podcaster ataupun materi yang disampaikan. Hal ini dikonfirmasi dari informan (AS) yang menyatakan: "kayak dari segi produksinya, suaranya dienakin, kesadaran si podcasternya juga lebih di utamain, udah gitu pembahasannya kaya yang tadi gue bilang tuh gaya ngomong ga terlalu ngelebar" (Informan AS; 6 Januari 2020). Selain itu informan (NA) juga menyatakan: "mengemangkan kontennya ibaratnya gimana caranya kontennya tetep seger, tetep terasa baru terus banyak mikirin juga kita bisa ngapain lagi ya dengan audio didalam podcast ini. Jadi usaha peningkatannya daripada ke strategi promosinya mending ke strategi kontennya, kita bisa ngapain lagi" (Informan NA; 3 Februari 2020). Setelah proses spreadability terhadap konten dan promosi, hal lain yang dapat dijalani yaitu melakukan engangement dengan pendengar.

Proses membangun engagement dengan pendengar podcast biasanya dilakukan langsung oleh para podcaster melalui sosial media yang dimiliki. Hal tersebut dikonfirmasi dengan pernyataan dari informan (NA) yang menyatakan: "Misalnya kita lagi ngebahas soal cinta, eksekusinya apa di Instagram kita bikin pertanyaan misalnya, kaya gitu-gitu" (Informan NA; 3 Februari 2020). Setelah kesembilan hal tadi yang digunakan, strategi terakhir dalam proses penyebarluasan podcast yaitu adanya dukungan pihak sekitar yang juga menjadi salah satu hal yang sangat membantu dalam proses ini. Dukungan pihak sekitar yang dimaksud disini adalah bentuk dukungan dari keluarga, teman, dalam bentuk verbal langsung atau bisa juga berbentuk dukungan melalui event tertentu yang diikuti. Hal ini terkonfirmasi dari informan (HD) yang menyatakan: "podcast pojokan pernah diundang ke acara kampus buat share soal kenapa lo pilih podcast? gimanasih di podcast? Minimal orang-orang yang dengerin saat itu jadi tau podcast gua, gitu cara dukung lingkungannya" (Informan HD; 11 Januari 2020) dan informan (NA) yang menyatakan: "Memberi ruang... untuk gua menentukan prioritas gua setiap selasa bikin RAPOT misalnya kaya gitu nah itu menurut gue itu salah satu bentuk dukungan juga" (Informan NA; 3 Februari 2020).

\section{Monetization}

Monetisasi selalu berhubungan dengan proses menghasilkan, dimana ada beberapa hal yang menjadi komponen berpengaruh dalam strategi monetisasi podcast di 
Indonesia. Pertama dengan mengecek aktivasi pendapatan melalui platform yang ada dapat digunakan atau tidak. Menurut hasil wawancara dengan informan, sebagai seorang podcaster mereka belum mendapatkan penghasilan tetap dari apa yang mereka kerjakan di podcast. Hal ini terkonfirmasi dari (NA) yang menyatakan: "kalau mau dibilang profesi kan gakada pemasukan tetap kaya gitu juga maksudnya ini kita gak digaji sama siapa-siapa" (Informan NA; 3 Februari 2020). Walaupun podcast sudah bisa menghasilkan uang diluar dari platform penyedia nya, namun tetap dengan adanya jumlah uang yang terlihat didalam platform penyedia podcast menimbulkan pertanyaan bagaimana cara untuk mengaksesnya dan menjadi salah satu masalah monetisasi yang harus dibahas. Hal ini dikonfirmasi oleh informan (AS) yang menyatakan: "regulasi yang belum gue pahami mungkin itu masalah gimana cara gua ngakses duit ini, sedangkan itu udah tertera kan ini duitnya sekian, cuman gimana caranya? " (Informan AS; 6 Februari 2020).

Bila belum berhasil memonetisasi podcast hanya mengandalkan aktivasi platform, lanjut dengan menghasilkan melalui pengalaman event yang dijalankan. Semenjak informan berperan sebagai seorang podcaster, mereka memang belum mendapatkan penghasilan tetap namun mereka sering hadir ke berbagai event, mulai dari menjadi $M C$ pada event tersebut, menjadi bintang tamu, bahkan hingga podcast mereka sendiri yang mengadakan event tersebut. Hal ini terkonfirmasi dari masing-masing informan yaitu informan (AS) yang mengatakan: "kalau di undang dari podcastnya itu belum banyak si, belum ada 5 kalau bener-bener satu utuh podcastnya dipanggil gitu, belum banyak. Tapi kalau dari MC, ada juga karena podcast itu" (Informan AS; 6 Januari 2020), informan (HD) yang menyatakan: "jadi si KPK pernah ngundang kita buat promosiin dana desa, em..korupsi di dana desa. Kita pernah diundang BTPN buat sharing soal kenapa pilih podcast, terus juga kita pernah mendukung suara yang namanya suara sunyi" (Informan HD; 11 Januari 2020), hingga informan (NA) yang menyatakan: "talkshow udah cukup banyak ya baik itu yang didakan kampus atau pun tarafnya nasional. Terus kayak nonton bareng tuh udah sering banget diajakin ibaratnya tuh kayak lo bikin activation nonton bareng dukung film Indonesia tertentu dong. Terus konten kayak media-media ngeliput RAPOT untuk di interview juga udah banyak lah udah beberapa. Terus paling kerjasama sama brand ya yang turunannya jadi macemmacem” (Informan NA; 3 Februaro 2020).

Kegiatan event merupakan bagian dari strategi monetisasi dan berkaitan dengan honor yang ditawarkan podcaster untuk mengundang podcast mereka sebagai bintang tamu ditentukan juga sesuai dengan event apa yang mereka datangi, yang pastinya setiap podcast memiliki standart honor masing-masing. Ada podcast yang telah menentukan ratecard atau tarif seperti yang terkonfirmasi dari informan (AS) yang menyatakan: "buat di podcastnya sendiri cuma angkanya masih kecil, 2.500.000." (Informan AS; 6 Januari 2020) dan informan (NA) yang menyatakan: "bisa start dari 15 juta untuk mendatangi kita ber-4" (Informan NA; 3 Februari 2020). Tapi masih ada juga podcast yang tidak menentukan honor mereka dan fleksibel mengenai pembayaran seperti salah 
satu informan (HD) yang menyatakan: “mungkin 500 sampe 800” (Informan HD; 11 Januari 2020).

Setelah beberapa aspek yang digunakan dan diperhatikan dalam proses monetisasi, ada hal baru yang juga ternyata dapat menperluas peluang monetisasi podcast berlangsung, yaitu dengan bergabung dalam podcast agency. Dalam dunia podcast ternyata tidak seluruh podcast berdiri sendiri. Ada juga podcast yang ternyata bergabung dengan sebuah perusahaan yang mengepalai berbagai macam podcast (semacam agency), dan mungkin dengan adanya perusahaan tersebut juga dapat memperjelas jendela penghasilan dari podcaster yang bergabung didalamnya. Hal ini dikonfirmasi dari informan (HD) yang menyatakan: "tapi mungkin dengan gabung box2box ini mungkin ada jendela baru buat ngehasilin uang lagi lewat podcast, tapi belum tau, mungkin nanti ada episode-episode khusus yang gabung sama brand atau sejenisnya tapi gue belum tau secara spesifik" (informan HD; 11 Januari 2020), masih dengan informan yang sama informan (HD) menambahkan dengan pernyataan: "nah kalo box2box itu gue gatau namanya apa mungkin agency" (Informan HD; 11 Januari 2020).

Nama dalam sebuah podcast tidak hanya dapat digunakan sebagai identitas podcast tersebut, melainkan dapat menjadi sebuah brand yang bisa cair ke dalam berbagain bentuk aktivasi lainnya dan menciptakan bertambahnya peluang monetisasi berlangsung yang dapat disebut sebagai pengembangan brand podcast. Hal ini terkonfirmasi dari informan (NA) yang menyatakan "RAPOT itu bukan cuma podcast tapi juga brand, jadi dia bisa cair masuk ke activation apapun" (Informan NA; 3 Februari 2020). Selanjutnya perolehan strategi monetisasi dengan melibatkan iklan dalam podcast. Memasukkan sebuah brand ke dalam konten podcast dapat menjadi salah satu pilihan yang baik untuk dilakukan. Proses memasukkan sebuah produk ke dalam konten yang dibuat bisa terbentuk salah satunya melalui adlibs pada konten podcast atau dapat juga dilakukan melalui media sosial podcast tersebut. Hal ini dikonfirmasi oleh informan (NA) yang menyatakan: "bisa selain podcast, live podcast terus activasion digital yang berhubungan dengan podcastnya, ada juga live instagram tapi itu bentuknya tetep kayak podcast cuma ga direkam masuk kedalam podcastnya" (Informan NA; 3 Februari 2020).

Selain mengelola podcast, seorang podcaster juga memiliki ratecard khusus untuk mengundang dirinya sebagai bintang tamu baik dalam talkshow atau event lainnya yang diadakan. Namun tetap fee yang ditawarkan telah disesuaikan dengan tujuan awal dari undangan tersebut dan siapa yang mengundangnya. Hal ini terkonfirmasi dari informan (NA) yang menyatakan: "gue tuh bener-bener cair banget misalnya dari 5juta atau lo cuma punya nya uang transport ya gapapa juga" (Informan NA; 3 Februari 2020).

Hasil wawancara pada penelitian ini menunjukkan terdapat tiga strategi utama dalam podcast komedi. Bila dlihat dari strategi Storytelling, hampir keseluruhan hal mempengaruhi dari mulai ciri khas podcaster yang terbentuk dengan sendirinya, pengaturan durasi, pergantian partner dalam berpodcast, hingga banyaknya referensi mengenai berbagai hal termasuk hal komedi yang ia miliki. Sedangkan hal berbeda 
ditemukan pada intonasi, dimana intonasi datar pun bisa menjadikan suatu materi tetap mudah dipahami dan komedi yang disampaikan tetap tersampaikan dengan baik, walaupun tetap harus didukung dengan materi pembahasan yang kuat. Kuat disini memiliki arti mempunyai unsur keterlibatan terhadap kehidupan sehari-hari. Sama halnya dengan sebuah pesan komunikasi yang disampaikan dan disusun berdasarkan sebuah topik pembicaraan yang ada, mulai dari hal yang penting kepada hal yang tidak terlalu penting hingga hal yang dikenal menuju hal hal yang asing (Nurhadi \& Kurniawan, 2017). Seperti itulah pentingnya proses storytelling podcast memiliki materi pembahasan yang kuat atau memiliki unsur keterlibatan dengan penerima pesan dan memiliki unsur menghibur didalamnya.

Begitu juga dengan hasil mengenai spreadability, dimana proses promosi dalam berbagai macam bentuk ternyata dapat membantu proses penyebarluasan podcast. Pada proses spreadability kita bisa menemukan cara baru dimana kita tidak hanya bisa melakukan promosi dengan cara menyebarkan podcast yang dimiliki, terbatas hanya melalui media sosial atau dari mulut ke mulut saja, melainkan dapat dilakukan dengan cara lain salah satunya melalui kolaborasi antar podcast. Lain hal dengan monetisasi, dalam hal menghasilkan, mayoritas informan menjawab bahwa podcast bukan sarana utama mata pencaharian podcaster. Namun peluang untuk menerima iklan berbayar pun tidak menutup kemungkinan untuk menjadi salah satu usaha memonetisasi dan beberapa marketer di Indonesia menganggap podcast adalah salah satu tempat yang menuguntungkan untuk menyebarkan sebuah iklan karena tidak bersifat selintas, iklan yang disajikan akan selalu ada selama episode tersebut masih ada di platform penyedia podcast tersebut (Rane, 2018). Kemudian masih ada hal yang harus disosialisasikan kembali yaitu dalam sistem penghasilan pembuatan podcast, seperti sistem claim yang ada di platform penyedia podcast yang masih belum banyak diketahui jelas cara pengambilannya oleh beberapa podcaster, dimana cara tersebut dapat mengakses uang yang didapat melalui hitungan jumlah pendengar podcast tersebut.

Penelitian ini podcaster lebih memilih untuk menjalankan podcast tanpa berharap besar melalui masa depan mereka, bahkan ada yang lebih memilih untuk menjadikan podcast sebagai saran hiburan mereka atau bahkan semata-mata ditujukan sebagai tempat menyalurkan hobi yang dimiliki. Walaupun memiliki pikiran tersebut, namun podcaster tetap tidak menolak hal baik yang mungkin akan muncul melalui podcast yang dimiliki dan ada juga dari mereka yang ingin menjadikan nama podcast mereka menjadi sebuah branding dan dapat cair kedalam berbagai aktivasi yang dibutuhkan. Berbeda dengan penelitian sebelumnya yang dilakukan di Amerika Serikat, beberapa komedian amatir beralih ke bidang podcast hanya sebagai cara agar mereka bisa didengarkan juga dan tidak kalah bersiang dengan komedian lainnya, namun beberapa pemain mapan seperti Marc Maron, Kevin Pollak dan Chris Hardwick, menggunakan podcast untuk mengembalikan karir mereka yang tertahan di media lainnya (Marx, 2015).

\section{PENUTUP}


Hasil analisis strategi storytelling, spreadability dan monetization podcast sebagai media baru komedi menemukan strategi storytelling, dimana podcaster menyampaikan materi podcast mereka secara natural menggunakan ciri khas podcaster masing-masing dan pastinya tetap membahas hal yang berhubungan dengan pengalaman sehari-hari yang dirasakan oleh beberapa masyarakat Indonesia. Salah satu hal yang berpengaruh cukup besar juga selain cara penyampaian atau ciri khas yang dimiliki yaitu partner podcaster dan mungkin akan berpengaruh besar dalam masa depan podcast mereka bila partner mereka digantikan dengan orang baru. Perhatian kecil perlu dilakukan dalam ber-podcast, pengulangan perkataan dan penghitungan durasi juga dapat mengancam pendengar akan berhenti mendengarkan ditengah jalan tanpa menyelesaikan durasi sepenuhnya. Melalui penelitian ini, kita bisa melihat bahwa komedi yang ada dalam podcast tidak terjadi karena hanya sekedar untuk menyampaikan unsur komedi itu sendiri, atau bahkan bukan untuk menjadi seorang komedian. Komedi dalam podcast dapat muncul berdasarkan sisi alamiah podcaster dalam membawakan materi atau bahkan bisa muncul dikarenakan materi yang dibawakan sudah memiliki unsur lucu tersendiri.

Spreadability, promosi konten merupakan hal yang sangat memiki keterkaitan erat mempengaruhi proses penyebarluasan suatu podcast. Podcast memiliki akses yang sangat luas dalam bidang promosi konten. Promosi bisa dilakukan melalui media sosial masing-masing podcaster, hingga media sosial khusus yang dimiliki podcast tersebut. Selain promosi online, kolaborasi antar podcast juga dapat mendatangkan pendengar baru bagi podcast yang terlibat didalamya. Adanya keterlibatan pihak yang sudah memiliki track record dalam bidang audio ke dalam podcast juga dapat membuat perkembangan podcast di Indonesia menjadi semakin terlihat dan terus bertambah setiap tahunnya.

Proses monetisasi, walaupun para podcaster tidak menjadikan podcast sebagai sumber mata pencaharian utama mereka, podcast terbukti dapat menghasilkan uang, namun bukan dalam bentuk gaji tetap, melainkan melalui kerjasama dengan brand, atau terlibat dalam sebuah event tertentu. Beberapa podcast mampu memiliki iklan dalam podcast mereka baik dalam konten audio yang mereka sajikan ataupun dalam bentuk aktivasi lain seperti live di media sosial yang mereka miliki, dimana iklan maupun event yang melibatkan podcast bisa ada salah satunya karena keberhasilan dari strategi penyebarluasan podcast serta strategi storytelling yang dilakukan sebelumnya.

Dengan berbagai macam konten audio yang ditawarkan, ada beberapa podcast yang membahas topik random dengan cara pengemasan konten yang berbeda-beda yaitu dengan melibatkan unsur candaan sehingga podcast tersebut bisa dikategorikan sebagai podcast komedi. Tapi ternyata dalam platform penyedia podcast, beberapa podcast merasa tidak dikategorikan sebagai podcast komedi secara resmi, namun mereka mendapat julukan podcast komedi dari respon pendengar podcast yang menganggap mereka sebagai podcast komedi, karena podcaster terbiasa menyampaikan materi dengan cara lucu menggunakan ciri khas podcaster masing-masing. 


\section{REFERENSI}

Asri, A. N., Indrianti, T., \& Perdanasari, N. (2017). Bahasa Inggris Di Program Studi Manajemen Informatika. 81-89.

Bogdan dan Taylor. 1975. Metodologi Penelitian Kualitatif. Bandung: Remadja Karya

Bongey, S. B., Cizadlo, G., \& Kalnbach, L. (2006). Explorations in course-casting : podcasts in higher education. https://doi.org/10.1108/10650740610714107

Eka, R. (2018). Laporan DailySocial: Penggunaan Layanan Podcast 2018. Retrieved November 25, 2019, from https://dailysocial.id/post/laporan-dailysocialpenggunaan-layanan-podcast-2018 website: https://dailysocial.id/post/laporandailysocial-penggunaan-layanan-podcast-2018

Fadilah, E., Yudhapramesti, P., \& Aristi, N. (2017). Podcast sebagai Alternatif Distribusi Konten Audio. Jurnal Kajian Jurnalisme, 1(1), 90-104. https://doi.org/10.24198/kj.v1i1.10562

Febriani, N., \& Fadilah, E. (2019). Penerapan Model MonetisasiContent Creation Pada Vice Indonesia. Jurnal Kajian Jurnalisme, 3(1), 177-197. https://doi.org/10.24198/kj.v3i1.21360

Junaid, I. (2016). Analisis data kualitatif dalam penelitian pariwisata. Jurnal Kepariwisataan, 10(1), 59-74.

Kaonang, G. (2018). Fitur Baru Anchor Permudah Kreator Podcast Memonetisasi Karyanya | Dailysocial. Retrieved November 25, 2019, from https://dailysocial.id/post/anchor-listener-support

Kusuma Pertiwi, W. (2019). Pendengar Podcast di Spotify Naik 50 Persen. Retrieved November 25, 2019, from https://tekno.kompas.com/read/2019/08/02/08050027/pendengar-podcast-dispotify-naik-50-persen

Marlina. (2016). DAYA TARIK FACEBOOK SEBAGAI MEDIA KOMUNIKASI ALTERNATIF Marlina Program Pascasarjana Universitas Islam Negeri Sumatera Utara. 1(1), 105-125.

Marx, N. (2015). Radio voices, digital downloads: bridging old and new media in the Onion Radio News podcast. Comedy Studies, 6(2), 107-117. https://doi.org/10.1080/2040610X.2015.1083166

Moleong, Lexy J. (2012). Metodologi Penelitian Kualitatif. Bandung : PT Remaja Rosdakarya.

Namira, I. \&, \& Wicaksono, B. D. (2020, May 29). 7 Fakta Perkembangan Podcast di Indonesia, Makin Banyak Penggemarnya! Retrieved August 13, 2020, from https://www.idntimes.com/tech/trend/izza-namira-1/perkembangan-podcast-di- 
indonesia/4

Nurhadi, Z., \& Kurniawan, A. (2017). KAJIAN TENTANG EFEKTIVITAS PESAN DALAM KOMUNIKASI. (1), 5.

Pew Research Center (2016). You searched for podcast: fact sheet edison research 2016 | Pew Research Center. Retrieved August 8, 2020, from 2016 website: https://www.pewresearch.org/search/podcast:+fact+sheet+edison+research+2016

Rane (2018). Artikel Tentang Podcasting | Blogfam. Retrieved August 9, 2020, from 2018 website: https://blogfam.com/category/artikel-tentang-podcasting/

Samosir, H. . \&, \& Putra, M. . (2020). Melihat Pelesat Progres Podcast di Indonesia. Retrieved August 13, 2020, from https://www.cnnindonesia.com/hiburan/20200227132308-241-478714/melihatpelesat-progres-podcast-di-indonesia

Spotify: Pendengar Podcast di Indonesia Terbanyak se-Asia Tenggara - kumparan.com. (2020, May 28). Retrieved August 13, 2020, from https://kumparan.com/millennial/spotify-pendengar-podcast-di-indonesiaterbanyak-se-asia-tenggara-1tV7zdmCpV0/full

Sya, M., Marta, R. F., \& Hadi, I. P. (2020). REFLEKSI PLURALISME MELALUI FILM ANIMASI SI ENTONG SEBAGAI IDENTITAS BUDAYA INDONESIA. 3(February), $18-33$.

Symons, A. (2017). Podcast comedy and 'Authentic Outsiders': how new media is challenging the owners of industry. Celebrity Studies, 8(1), 104-118. https://doi.org/10.1080/19392397.2016.1217162

Thaba, A. \& R. (2013). KEEFEKTIFAN TEKNIK STORY TELLING DALAM PEMBELAJARAN SASTRA. Journal of Chemical Information and Modeling, 53(9), 1689-1699. https://doi.org/10.1017/CBO9781107415324.004

Toyib, M., Humaisyi, S., \& Muzakki, M. H. (2013). Penggunaan Podcast Dalam (Stad) Untuk Meningkatkan Kemampuan Menyimak Pada Mata Kuliah Listening I Prodi Tadris Inggris Jurusan Tarbiyah Stain Ponorogo. Kodifikasia, 6(1). https://doi.org/10.21154/kodifikasia.v6i1.204

Zaenudin, A. (2011). Hikayat Podcast - Tirto.ID. Retrieved November 25, 2019, from https://tirto.id/hikayat-podcast-cufm 